\title{
Functional, Structural, and Neurotoxicity Biomarkers in Integrative Assessment of Concussions
}

\section{Svetlana A. Dambinova ${ }^{1 \star}$, Joseph C. Maroon ${ }^{2}$, Alicia M. Sufrinko ${ }^{3}$, John David Mullins ${ }^{4}$, Eugenia V. Alexandrova ${ }^{5}$ and Alexander A. Potapov ${ }^{5}$}

${ }^{1}$ Brain Biomarkers Research Laboratory, DeKalb Medical Center, Decatur, GA, USA, ${ }^{2}$ Neurological Surgery, University of Pittsburgh, Pittsburgh, PA, USA, ${ }^{3}$ Orthopaedic Surgery, University of Pittsburgh, Pittsburgh, PA, USA, ${ }^{4}$ Surgery, Piedmont Hospital, Atlanta, GA, USA, ${ }^{5}$ Neurotrauma, Burdenko Neurosurgery Institute, Moscow, Russia

Concussion is a complex, heterogeneous process affecting the brain. Accurate assessment and diagnosis and appropriate management of concussion are essential to ensure that athletes do not prematurely return to play or others to work or active military duty, risking re-injury. To date, clinical diagnosis relies primarily on evaluating subjects for functional impairment using instruments that include neurocognitive testing, subjective symptom report, and neurobehavioral assessments, such as balance and vestibular-ocular reflex testing. Structural biomarkers, defined as advanced neuroimaging techniques and biomarkers assessing neurotoxicity and immunoexcitotoxicity, may complement the use of functional biomarkers. We hypothesize that neurotoxicity AMPA, NMDA, and kainite receptor biomarkers might be utilized as a part of comprehensive approach to concussion evaluations, with the goal of increasing diagnostic accuracy and facilitating treatment planning and prognostic assessment.

Keywords: concussion, mild TBI, neuropsychological evaluations, advanced MRI sequences, neurotoxicity and neuroplasticity biomarkers

\section{INTRODUCTION}

Concussion is a heterogeneous injury that requires a multifaceted and comprehensive approach for assessment, diagnosis, and management. Several clinical tools are routinely used, including symptom report, neurocognitive testing, and postural stability/vestibular and oculomotor assessments (1). However, these tools, which represent functional biomarkers, have practical limitations and may not possess adequate sensitivity in diagnosing all concussions. More objective means of assessment, including advanced neuroimaging techniques and neurotoxicity biomarkers, have gained research attention. These may facilitate diagnosis and could potentially assist with monitoring recovery and determining prognosis. Preliminary studies suggest neurotoxicity biomarkers, in conjunction with neurocognitive testing, might improve diagnostic certainty of suspected concussions and may provide valuable information on what domains of brain function are affected (e.g., vestibular system) or the severity of a concussion (2). This may be particularly valuable, since the grading scales for concussion severity are not scientifically validated, lack prognostic utility, and are largely considered antiquated or outdated (3). 
Laboratory chemistry tests confirm systemic changes of energy metabolites in concussion (e.g., ATP, creatine, lactate, as well as blood gases and minerals) (4). Quantitative values of brain-borne neurotoxicity degradation fragments of ionotropic glutamate receptors (GluRs) and antibodies to excitotoxicity biomarkers in blood are important early markers of injury (5). Therefore, these biomarkers, when added to a comprehensive evaluation of concussion, may improve diagnosis and prognosis. The purpose of this review is to highlight the potential role of neurotoxicity biomarkers in a comprehensive evaluation of sports-related concussion.

\section{CLINICAL DEFINITIONS: CONCUSSION}

Concussion is defined as a "complex pathophysiological process affecting the brain, induced by biomechanical forces," with associated traumatically induced alteration in mental status with or without loss of consciousness, as specified in a recent consensus statement on concussion in sports (6). Several physical, cognitive, emotional, somatic, and sleep-related symptoms may be present for days to weeks following injury. These are linked to cognitive, vestibular, and oculomotor dysfunction of various brain systems or domains (6). The terms "concussion" and "mild traumatic brain injury" (mTBI) are proposed to be used interchangeably, since much of the clinical symptomology overlaps and as many as $80 \%$ of concussions are diagnosed as mTBI. Neither mTBI nor concussive injuries show gross abnormalities on standard neuroimaging, and most patients recover without permanent impairment (7, 8). Typically, about $80 \%$ of post-concussive symptoms resolve spontaneously within 7-10 days of the acute phase (6).

\section{BIOMECHANICS OF INJURY}

Rotational forces can cause a transient disruption of function in the reticular activating system, resulting in the loss of consciousness associated with concussion (9). Prior biomechanical data have demonstrated that a simple impact of the head with a solid surface (rotational acceleration $>5,000 \mathrm{rad} / \mathrm{s}^{2}$ ) leads to the greatest stress-strain to the frontotemporal regions, connecting limbic structures as well as the corpus callosum and cortical-spinal tract (10). As a result, rotational acceleration, diffuse shear, and strain forces cause variable degrees of injury to neurons, glia, the blood-brain barrier (BBB), and vascular structures, leading to transitory ionic functional disturbances with clinical manifestations. These include sudden confusion, lack of balance or coordination, vision abnormalities, and memory impairment (11). Despite using advanced techniques, such as the head impact telemetry system (HITS), researchers have not been able to diagnose concussion reliably by quantifying a specific threshold (12). Researchers argue that the validity of head impact metrics has not been adequately addressed for sports, and clinicians have been cautioned to not rely on impact magnitude or location to predict acute clinical outcomes, symptom severity (Table 1), neuropsychological function, or balance abnormalities $(10,13)$.

\section{FUNCTIONAL BIOMARKERS: CLINICAL ASSESSMENT}

Clinical assessment of concussion is structured around the various domain-specific impairments exhibited following

TABLE 1 | Biomechanical attempts to assess severity of concussion.

\begin{tabular}{|c|c|c|c|c|c|}
\hline \multirow[t]{2}{*}{ Severity } & \multicolumn{2}{|c|}{ Characteristics } & \multicolumn{2}{|c|}{ Transitory disturbances } & \multirow[t]{2}{*}{ Reference } \\
\hline & $\begin{array}{l}\text { Impact force in gravity force }(\mathrm{g}) \text { and } \\
\text { radian per seconds }\left(\mathrm{rad} / \mathrm{s}^{2}\right)\end{array}$ & Impact location & Frequent symptoms & $\begin{array}{l}\text { Symptom } \\
\text { duration }\end{array}$ & \\
\hline \multirow[t]{5}{*}{ Mild } & Direct impact & & & & \\
\hline & $\begin{array}{l}\text { Linear acceleration } \sim 30-65 \mathrm{~g} \\
\text { Time } \sim 1 \mathrm{~ms}\end{array}$ & Frontal, parietal, and temporal lobes & $\begin{array}{l}\text { Often no symptoms, no } \\
\text { functional changes }\end{array}$ & About $24 \mathrm{~h}$ & $(14)$ \\
\hline & Rotational acceleration - 4,000-5,000 rad $/ \mathrm{s}^{2}$ & Brainstem, spinal tract & & & $(15)$ \\
\hline & Coup-countercoup $\left(\mathrm{AIS}^{\mathrm{a}}=1\right)$ & & & & (16) \\
\hline & $\begin{array}{l}\text { linear acceleration 50-100 g } \\
\mathrm{ICP}^{\mathrm{b}}<173 \mathrm{kPa}\end{array}$ & $\begin{array}{l}\text { Frontal lobe and upper end of } \\
\text { brainstem }\end{array}$ & & & \\
\hline \multirow[t]{5}{*}{ Moderate } & Direct impact & & & & \\
\hline & $\begin{array}{l}\text { Linear acceleration 70-90 g } \\
\text { Time } \sim 1-3 \mathrm{~ms}\end{array}$ & Frontal, parietal, and temporal lobes & $\begin{array}{l}\text { No outward symptoms } \\
\text { but substantial functional }\end{array}$ & $1-3$ days & $(17)$ \\
\hline & Rotational acceleration - 5,000-6,500 rad/s $\mathrm{s}^{2}$ & Brainstem, spinal tract & alterations & & $(10)$ \\
\hline & Coup-countercoup (AIS = 2) & & & & \\
\hline & $\begin{array}{l}\text { linear acceleration } \sim 100-150 \mathrm{~g} \\
\mathrm{ICP} \sim 140-190 \mathrm{kPa}\end{array}$ & $\begin{array}{l}\text { Frontal lobe and upper end of } \\
\text { brainstem }\end{array}$ & & & $(18)$ \\
\hline \multirow[t]{4}{*}{ Severe } & Direct impact & & & & \\
\hline & $\begin{array}{l}\text { Linear acceleration >100 g } \\
\text { Time }-4 \mathrm{~ms}\end{array}$ & Frontal, parietal, and temporal lobes & $\begin{array}{l}\text { Often but not always clinically } \\
\text { observed functional impairment }\end{array}$ & Up to $2-3$ weeks & (19) \\
\hline & $\begin{array}{l}\text { Rotational acceleration } \sim 7,000-13,000 \mathrm{rad} / \mathrm{s}^{2} \\
\text { Coup-countercoup (AIS }=3-4 \text { ) }\end{array}$ & Brainstem, spinal tract & & & (20) \\
\hline & $\begin{array}{l}\text { Linear acceleration } \sim 150-250 \mathrm{~g} \\
\mathrm{ICP} \sim 201-282 \mathrm{kPa}\end{array}$ & $\begin{array}{l}\text { Frontal lobe and upper end of } \\
\text { brainstem }\end{array}$ & & & \\
\hline
\end{tabular}

${ }^{a} A / S$ - Abbreviated Injury Scale.

' $/ C P$ - intracranial pressure. 
injury - cognitive, vestibular, somatic, and emotional - adapted for various settings, such as on the "sideline" at sporting events as well as during recovery following acute, subacute, and chronic injury (Table 2).

\section{Sideline Assessment}

The Standardized Concussion Assessment Tool and its revisions (SCAT2, SCAT3) are the most widely used tools on the sideline (31). These comprise a number of empirically validated measures adapted across several domains of assessment, including symptom report, mental status, attention/memory, and balance. The SCAT is "likely to identify the presence of concussion in the early stages of post-injury," according to the 2013 American Academy of Neurology concussion guidelines (32). Others argue that this tool is insensitive to identifying mild deficits, and is subject to practice effects (33). Furthermore, it should not be relied on for decisions regarding whether an athlete should be allowed to return to play (34). The Display Enhanced Testing for Concussions and mTBI (DETECT) system has been developed in response to the need for a fast and efficient sideline neuropsychological test (35). It is a 7-min battery of tests that allows for real-time cognitive testing in situations previously deemed impractical or unavailable for patients with concussion, such as the sideline. However, it is still being examined for validity and reliability.

\section{Neurocognitive Testing}

Neurocognitive testing has been coined a "cornerstone" of concussion management since the initial Concussion in Sport Group meeting in 2001. Typically, neurocognitive testing is completed in an office or quiet setting, and has been shown to be sensitive both to acute deficits (e.g., $<24 \mathrm{~h}$ following injury) as well as those detected after an athlete is symptom free $(36,37)$. Of all the commercially available computerized test batteries, the Immediate Post-concussion and Cognitive Testing Test Battery (ImPACT) is the most widely used and researched and the only one formally approved by the FDA; others are summarized in Table 2. Although largely reserved for those with protracted recoveries, for some athletes, traditional paper and pencil neuropsychological testing may be a component of concussion protocols. While neurocognitive evaluation is essential in assessing and managing concussion in a majority of cases, it is important to recognize that neurocognitive deficits are occasionally absent following concussion. A recent meta-analysis of computerized neurocognitive tests (CNTs) suggests an overall low-to-moderate magnitude of effects size, attributing these findings to the heterogenic nature of concussion (38). There are other limitations in using neurocognitive testing following concussion. Several extraneous factors may influence neurocognitive test performance, including motivation, effort, sleep, pain, and anxiety (39). Neurocognitive testing

TABLE 2 | Test battery for concussion assessment.

\begin{tabular}{|c|c|c|c|c|}
\hline Tools & Intended use & Properties & Limitations & Reference \\
\hline \multicolumn{5}{|l|}{ Sideline } \\
\hline $\begin{array}{l}\text { Sports concussion } \\
\text { assessment tool (SCAT3) }\end{array}$ & $\begin{array}{l}\text { Sideline assessment } \\
\text { diagnostic }\end{array}$ & $\begin{array}{l}\text { Sensitivity } 80-94 \% \\
\text { Specificity } 76-91 \%\end{array}$ & Should not be used for return to play decisions & $(21)$ \\
\hline \multicolumn{5}{|c|}{ Computerized neurocognitive tests } \\
\hline $\begin{array}{l}\text { Immediate post-concussion } \\
\text { and cognitive testing } \\
\text { (ImPACT) }\end{array}$ & $\begin{array}{l}\text { In office, diagnosis } \\
\text { and management }\end{array}$ & Sensitivity 82-91\% & $\begin{array}{l}\text { Must have a trained professional for interpretation; } \\
\text { potential for misuse (e.g., poor control on } \\
\text { environment, use as a standalone measure) }\end{array}$ & $\begin{array}{l}\text { (22, 23) http://www. } \\
\text { impacttest.com/ }\end{array}$ \\
\hline & & $\begin{array}{l}\text { Specificity } 69-89 \% \\
\text { Test-retest reliability } \\
0.25-0.85\end{array}$ & & \\
\hline Automated Neurocognitive & In office, diagnosis & Test-retest reliability & & (24) http://www. \\
\hline Assessment Metrics (ANAM) & and management & $0.14-0.81$ & & $\begin{array}{l}\text { vistalifesciences.com/ } \\
\text { index.php/anam-intro.html }\end{array}$ \\
\hline $\begin{array}{l}\text { Axon Sports Computerized } \\
\text { Cognitive Assessment Tool }\end{array}$ & $\begin{array}{l}\text { In office, diagnosis } \\
\text { and management }\end{array}$ & $\begin{array}{l}\text { Test-retest reliability } 0-0.94 \\
\text { (53\% of ICC's failing minimum } \\
\text { standards) }\end{array}$ & & www.axonsports.com/ \\
\hline Concussion Vital Signs & $\begin{array}{l}\text { In office, diagnosis } \\
\text { and management }\end{array}$ & $\begin{array}{l}\text { Test-retest reliability } \\
0.07-0.87\end{array}$ & & $\begin{array}{l}\text { http://www. } \\
\text { concussionvitalsigns.com/ }\end{array}$ \\
\hline \multicolumn{5}{|l|}{ Postural Stability/Vestibular } \\
\hline $\begin{array}{l}\text { Balance error scoring system } \\
\text { (BESS) }\end{array}$ & Sideline/Acute & $\begin{array}{l}\text { Specificity up to } 91 \% \\
\text { Sensitivity } 34-64 \%\end{array}$ & $\begin{array}{l}\text { Practice effects, poor intra/inter/after season } \\
\text { reliability }\end{array}$ & $(25,26)$ \\
\hline $\begin{array}{l}\text { Sensory organization test } \\
\text { (SOT) }\end{array}$ & In office & $\begin{array}{l}\text { Sensitivity } 48-61 \% \\
\text { Specificity of } 85-90 \%\end{array}$ & & $(27)$ \\
\hline $\begin{array}{l}\text { Vestibular/oculomotor } \\
\text { screening test (VOR, VMS) }\end{array}$ & In office & & Relies heavily on symptom report & (28) \\
\hline \multicolumn{5}{|l|}{ Oculomotor tests } \\
\hline Eye-Track Advance (ETA) & Sideline assessment & $\begin{array}{l}\text { Sensitivity } 54-77 \% \\
\text { Specificity of } 67-92 \%\end{array}$ & $\begin{array}{l}\text { Depends on past medical history, medications, } \\
\text { and drugs used }\end{array}$ & (29) \\
\hline King-Devick (K-D) test & Sideline & Test-retest reliability 0.90 & Practice effects, requires baseline & (30) \\
\hline $\begin{array}{l}\text { Vestibular/oculomotor } \\
\text { screening test (saccades, }\end{array}$ & In office & $\begin{array}{l}\text { Internal consistency } \\
\text { (Cronbach's alpha = 0.92) }\end{array}$ & Relies heavily on symptom report & $(28)$ \\
\hline
\end{tabular}

near point convergence) 
can be challenging to interpret among subpopulations, such as individuals with learning disabilities or attention deficits in the absence of baseline testing (40).

\section{Postural Stability/Vestibular}

Assessing balance and postural stability may be useful in the acute stages of injury (25). The Balance Error Scoring System (BESS) is the most widely used balance assessment following concussion, due to its rapid ease of administration and low cost. However, the system's sensitivity has been criticized because of the influence of other factors, such as fatigue, type of sport, and history of ankle injury or instability (41). The Sensory Organization Test (SOT) evaluates dynamics in postural stability using a force plate, and has superior reliability compared to the BESS (27). However, it is not feasible to use on the sideline due to the required equipment. Furthermore, similar to neurocognitive testing, deficits in postural stability are not always present after concussion or may resolve rapidly. Another tool developed for concussion assessment is the vestibular/ocular motor screening (VOMS) (28), which uses several tests for screening central vestibular functioning, including the vestibular-ocular reflex and visual-motion sensitivity.

\section{Oculomotor Assessment}

Both subjective and objective measures of oculomotor functioning have utility in diagnosis and management of concussion. The VOMS measures near point of convergence and provocation of symptoms on saccades, both sensitive to concussion (28), and correlates with neurocognitive impairment (42). The KingDevick $(\mathrm{K}-\mathrm{D})$ is a $1-\mathrm{min}$ test in which the athlete is asked to read, quickly and accurately, several pages of single-digit numbers that are arrayed left to right in columns that do not vertically align (43). Preliminary evidence suggests K-D is easily administered, can differentiate concussed from non-concussed athletes, and has high test-retest reliability $(r=0.90)(44)$. However, there is concern regarding practice effects (45). The objective eye-tracking technology concussion test, used in both sports and combat settings, records the subject visually tracking a target as it moves through a circular trajectory (46). Gaze error variability has been found to correlate significantly with attention and working memory measures on neurocognitive testing (29).

\section{NEUROIMAGING}

Concussion is generally regarded as a functional, rather than a structural, brain injury, with conventional neuroimaging findings considered normal and adding little value to clinical management of this injury beyond ruling out more severe pathology, such as a skull fracture or intracranial hemorrhage (47).

However, advanced magnetic resonance imaging (MRI) methods have demonstrated the ability to detect and localize pathophysiologic consequences of concussion or mTBI (48). Functional MRI (fMRI) data have shown a strong link between brain region functioning vs. concussion severity and time to recovery; however, this procedure is used primarily in the research setting (49). Diffusion tensor imaging (DTI)/DTIbased tractography is used to evaluate axonal tearing after the impact. Quantitative high-resolution imaging techniques, such as susceptibility-weighted imaging (SWI) or angiography (SWAN), depict iron deposits in brain microvessels, while cerebrovascular dysfunction in areas of hyper- or hypoperfusion can be detected by high-resolution diffusion-weighted imaging (DWI).

Recent studies that used SWI or perfusion-weighted imaging (PWI) with DTI and magnetic resonance (MR) spectroscopy found abnormalities in $80 \%$ of patients with mTBI when these three imaging modalities were collated $(50,51)$.

\section{Diffusor Tensor Imaging}

Diffusion tensor imaging (3T DTI)-based tractography evaluates diffuse axonal injury (DAI). Additionally, 3T fluid-attenuated inversion recovery (FLAIR) imaging allows detection of nonhemorrhagic DAI (47) and could potentially assist in assessment of structural abnormalities in concussions. Due to success in assessing a population with moderate-to-severe TBI, DTI has gained popularity for use in mTBI because of its enhanced technical resolution. DTI can reveal white matter alterations affecting the corticospinal tract (CST); the internal capsule; the corpus callosum (52); the inferior/superior, longitudinal, and fronto-occipital fasciculi; and the posterior thalamic and acoustic radiations in athletes following sports concussions (53). While increased fractional anisotropy (FA) numbers indicate reversible changes in white matter, reduced FA values reflect a loss of white matter integrity in a region of interest (54-56). Overall, data from DTI studies of mTBI have been contradictory, however, showing both increased FA values in acute and chronic studies $(57,58)$ as well as decreased FA levels (59). Recently, Davenport et al. (60) demonstrated that a single football season can produce alterations in DTI parameters in the absence of clinical concussion.

\section{Diffusion-Weighted Imaging}

Microvessel dysfunction can be detected by high-resolution DWI. DWI allows for differentiation between cytotoxic edema (restricted diffusion) and vasogenic edema (increased diffusion), and has been shown to identify shearing injuries not evident on T2/FLAIR or gradient echo sequences (61). Significant involvement of the neurovascular unit has also been shown in pediatric patients with sports-related concussions who experienced persistent symptoms (50). Recent MRI-based studies assessing cerebral flow alterations due to concussions and mTBI are indicating the emerging concept of concussion as a form of cerebrovascular disease (62).

\section{Susceptibility Weighted Imaging}

Small hemorrhages in white matter have been detected by high-resolution SWI in retrospective studies of retired NFL players (63), youths with sports-related concussion (64), and, in amateur boxers, more severe cases of mTBI (65). Significant SWI hypointensity alterations in brains of adult male hockey players within a single season have been observed in the subacute stage of injury compared to baseline images (66). However, SWI does not provide quantitative measures of magnetic susceptibility (67). 


\section{Susceptibility-Weighted Angiography}

As with SWI, SWAN focuses on intracerebral small vessels for identifying cerebral hemorrhage and calcifications (68) by visualizing measurable changes in cerebral veins due to hypoxia (69). It is particularly useful in visualizating microhemorrhages and lesions near the skull base (70), and has contributed to a proposed MRI grading scale $(71,72)$. Application of susceptibility-weighted imaging mapping (SWIM) for quantitative assessment (67) of venous blood oxygenation in the acute stage of mTBI has shown an excess of oxygen in impacted areas that may reflect a neuroprotective response following the injury (73).

In summary, several MRI sequences (DTI, DWI, FLAIR, SWI, SWAN) may be valuable in determining the location and level of microstructural abnormalities (micro-lesions) and edema following concussion. However, to date, MRI studies for mTBI are limited by study design, including consensus in methodology; e.g., 1.5 or 3T, sequence, slice thickness, and spatial resolution (74). Furthermore, there is often variability in timing after injury, age of subjects, severity of injury, and brain region analyzed. Additionally, use of advanced imaging-derived techniques, such as DTI, with multi-shell diffusion and highdefinition tractography modeling might be useful in identifying subtle structural changes due to mild concussion (52). The development of universal and more inclusive protocol(s) for mTBI studies might help overcome current limitations in pursuit of comparable, reproducible data.

\section{GLUTAMATER RECEPTOR BIOMARKERS}

Biomarkers for concussion can be categorized as diagnostic or prognostic/monitoring $(75,76)$. Prospective, diagnostic biomarkers provide information about a disease or condition and may assess the severity of concussion. Prognostic biomarkers (risk assessment) are defined as indicators that may provide the anticipated natural history of a disorder in the absence of a therapeutic intervention. Monitoring biomarkers (recovery) are used to follow a previously diagnosed or established disease or condition; for example, in making a decision whether a person should be returned to play in sports or to work or active military duty.

\section{Diagnostic Potential}

Ideal biomarker(s) for the diagnosis of concussion should (i) reflect the origin of transient subtle brain injury resulting from the impact and show a specific location of subtle brain injury, (ii) include detectable biological markers at an early stage of brain damage (within minutes to hours after event), (iii) correlate with performance on clinical measures, and (iv) demonstrate functional deficits or metabolic disturbances concurrent with advanced neuroimaging (fMRI, DTI, and SWI modalities). Several candidate brain biomarkers are associated with concussion severity (Table 3).

Neurotoxicity biomarkers include the ionotropic GluRs. The AMPA receptors (AMPAR; GluR1 subtype) are located

TABLE 3 | Candidate biomarkers for identification of concussions severity.

\begin{tabular}{|c|c|c|c|c|c|c|}
\hline \multirow[t]{2}{*}{ Biomarker } & \multicolumn{3}{|c|}{ Performance characteristics } & \multirow[t]{2}{*}{ Strengths (intended use) } & \multirow[t]{2}{*}{ Limitations (biomarker studies) } & \multirow[t]{2}{*}{ Reference } \\
\hline & $\begin{array}{l}\text { Cut off } \\
\mathrm{ng} / \mathrm{ml}\end{array}$ & $\begin{array}{c}\text { Sensitivity } \\
\%\end{array}$ & $\begin{array}{c}\text { Specificity } \\
\%\end{array}$ & & & \\
\hline AMPAR peptide & 0.4 & 89-91 & $91-92$ & $\begin{array}{l}\text { Associated with diffuse axonal injury } \\
\text { (DAI) }\end{array}$ & $\begin{array}{l}\text { Need data assessed within } 24 \mathrm{~h} \text { after } \\
\text { concussion }\end{array}$ & $(77)$ \\
\hline NMDAR peptide & 1.0 & 83 & 91 & $\begin{array}{l}\text { A biomarker of microvessel damage } \\
\text { and correlates with development of } \\
\text { cortical vasogenic edema }\end{array}$ & $\begin{array}{l}\text { Need to be assessed within } 24 \text { h after } \\
\text { concussion }\end{array}$ & (5) \\
\hline $\begin{array}{l}\text { Calpain-derived } \alpha \text { ll- } \\
\text { spectrin N-terminal } \\
\text { fragment (SNTF) }\end{array}$ & $\begin{array}{l}\text { Not } \\
\text { established }\end{array}$ & 100 & 75 & $\begin{array}{l}\text { Associated with DAI and shows white } \\
\text { matter abnormalities }\end{array}$ & $\begin{array}{l}\text { Low levels in biological liquids for mTBI. } \\
\text { There are no concussion studies }\end{array}$ & $(78)$ \\
\hline $\begin{array}{l}\text { Breakdown products } \\
\text { of glial fibrillary acidic } \\
\text { protein (GFAP-BDP) }\end{array}$ & 0.03 & $60-93$ & $75-97$ & $\begin{array}{l}\text { Detects hemorrhage/hematoma and } \\
\text { might be used to reduce unnecessary } \\
\text { CT/MRI }\end{array}$ & $\begin{array}{l}\text { GFAP-BDP also releases during intracerebral } \\
\text { and subarachnoid hemorrhagic strokes. } \\
\text { There are no concussion studies }\end{array}$ & (79) \\
\hline GFAB autoantibody & $2.9-3.0$ & - & - & $\begin{array}{l}\text { Shows dynamic interactions between } \\
\text { post-injury and specific autoimmune } \\
\text { response }\end{array}$ & Small sample size of the study & (80) \\
\hline $\begin{array}{l}\text { Kainate receptor } \\
\text { peptide }\end{array}$ & 0.5 & $83-90$ & 83-92 & $\begin{array}{l}\text { Might be associated with brainstem } \\
\text { injury and regulates venous circulation } \\
\text { (development of cytotoxic edema) }\end{array}$ & $\begin{array}{l}\text { Need to be assessed within } 24 \mathrm{~h} \text { after } \\
\text { concussion }\end{array}$ & (81) \\
\hline S-100B & $\begin{array}{l}0.06 \\
0.12\end{array}$ & $\begin{array}{l}94 \\
29\end{array}$ & $\begin{array}{l}50 \\
96\end{array}$ & $\begin{array}{l}\text { A marker of compromised blood-brain } \\
\text { barrier }\end{array}$ & Lack of specificity & (82) \\
\hline Total Tau protein & - & $\begin{array}{l}\text { Area under cur } \\
(95 \% \mathrm{Cl}, 0.81-\end{array}$ & $\begin{array}{l}\text { ve: } 0.91 \\
1.00)\end{array}$ & $\begin{array}{l}\text { Correlates to severity of concussions } \\
\text { and predicts longevity of recovery }\end{array}$ & Small sample size of the study & (83) \\
\hline UCHL1 & - & $\begin{array}{l}\text { Area under cur } \\
(95 \% \mathrm{Cl}, 0.57- \\
0.72\end{array}$ & $\begin{array}{l}\text { ve: } 0.62 \\
0.71)\end{array}$ & $\begin{array}{l}\text { A potential diagnostic assessment of } \\
\text { acute TBI } \\
\text { Associated with outcome }\end{array}$ & $\begin{array}{l}\text { UCHL1 found in more severe TBI. Limited } \\
\text { concussion studies }\end{array}$ & $(84,85)$ \\
\hline
\end{tabular}


exclusively in synaptic terminals (77) and could indicate diffuse dendritic-axonal injury (86). AMPAR is primarily distributed in the forebrain and subcortical pathways, including the hippocampus, amygdala, thalamus, hypothalamus, and brain stem $(87,88)$. These regions of the brain are predictable sources of biomarkers given the functional spatial-temporal coherence, developmental pathways, and cerebral plasticity affected by mild brain injury (89). The NMDA receptors (NMDAR: NR2 subtypes) are localized on the epithelial surface of microvessels that form the $\mathrm{BBB}$ and regulate cerebral arterial microvascular function (90). The biomechanical forces that lead to concussion may cause mechanical damage and energy failure in parenchymal cells and endothelia that comprise the BBB. Furthermore, concussion drives neurotoxicity biomarker peptides to be released continuously into the bloodstream through the compromised BBB within hours to days after impact. During the acute phase of concussion, a massive release of glutamate upregulates excitotoxic AMPAR $(55,91)$. The GluR1-subunit of N-terminal AMPAR fragments are rapidly cleaved by extracellular proteases and released into the bloodstream, where this degradation product, identified as a biomarker of neurotoxicity, can be directly detected (peptide fragment of 5-7 kD).

A feasibility study examining the diagnostic potential of the AMPAR peptide assay was conducted by administering neuropsychological testing (ImPACT) and neuroimaging to concussed athletes $(20.8 \pm 1.8$ years old, $56 \mathrm{M} / 28 \mathrm{~F}, 1-2$ weeks post-concussion, GCS $=14-15)$ and age-, gender-matched healthy controls $(21 \mathrm{M} / 19 \mathrm{~F})$ in conjunction with measurements of the biomarker (86). The sensitivity (91\%) and specificity (92\%) of AMPAR peptide to assess acute and semi-acute concussions (preliminary cut off of $0.4 \mathrm{ng} / \mathrm{mL}$ ) in college athletes was established. Additionally, in athletes with multiple concussions, worse ImPACT scores on processing speed, reaction time, and cognitive efficiency correlated with abnormal levels of AMPAR peptide (2.0-12.0 ng/mL) and DAI changes apparent on MRI (2).

Kainate receptors (KAR, GluR5/6), which are located mostly in the hippocampus, subcortical areas, spinal cord tract, and brainstem (92), might potentially affect cerebral venous circulation. Glutamate serves as a neuromediator for the medulla involved in regulation of involuntary life sustaining functions, such as breathing, swallowing, heart rate, and consciousness (92), primarily through KAR (2). In patients with mTBI, the decrease of venous function due to a rise in venous oxygenation in the affected thalamostriate and right basal areas (93) might involve KAR. As a component of post-military deployment mTBI screening, KAR peptide detection in active duty military personnel (37M/16F, 23.0 \pm 1.2 years old, 1 week after blast injury, GCS $=13-15)$ with impaired venous circulation in cervical areas defined by dopplerography yielded an optimal cut-off value of $1.0 \mathrm{ng} / \mathrm{mL}$ (90\% sensitivity, $83 \%$ specificity), at which a positive predictive value of $93 \%$ was achieved. A clinical study conducted with civilians who sustained $\mathrm{mTBI}(25 \mathrm{M} / 20 \mathrm{~F}, 30.1 \pm 3.0$ years old, GCS $=13-15$ ) and admitted to ED within $24 \mathrm{~h}$ after the impact due to violence-related events, motor vehicle crashes, and incidental falls showed KAR peptide sensitivity of $83 \%$ and specificity of $92 \%$ (cut-off of $0.5 \mathrm{ng} / \mathrm{mL}$ ), with a significant positive likelihood ratio of 10.5 to assess severe concussions (unpublished data). Notably, AMPAR and NR2 peptides were also abnormal in these cohorts.

\section{Prognostic/Monitoring Approaches}

Biomarkers intended to measure recovery following concussion should potentially (i) reflect neurological symptoms, (ii) identify the immune system response to inflammation, (iii) further predict outcomes, and (iv) assist with treatment/therapy recommendations.

Disruption of the BBB due to biomechanical force is believed to cause instantaneous increase in brain vasculature permeability, with both immediate and delayed pathogenic consequences $(7,94)$. The effects of a compromised BBB are exacerbated when accompanied by an immunological response initiated by entry of peripheral anti-CNS autoantibodies (95-97), which may be prognostic biomarkers of brain injury (98). Due to the nature of the normal immune response, antibodies to brain antigens detected in serum are typically associated with advanced or chronic conditions of brain damage $(99,100)$, whereas neuronal antigens measured in plasma are more likely to reflect acute injuries (101).

Early experimental and clinical research of antibodies to GluR1 subtype of AMPA receptors as an immunoexcitotoxicity biomarker has demonstrated their diagnostic value in detecting pathological brain-spiking activity and epileptic seizures $(102,103)$ as a consequence of traumatic brain injury, thereby representing a prognostic risk factor. Above threshold increases of AMPAR antibodies measured in serum of children $(n=60$, 7-16 years old) with chronic posttraumatic headache within 6-12 months after sustained single or multiple concussions were correlated with abnormal brain-spiking activity on EEG (104). Clinical studies of GluR1 antibodies in adult patients with different chronic neurological pathology $(n=1866)$ performed in Russia, Europe, and the USA have demonstrated diagnostic potential (sensitivity of $86-88 \%$, specificity of $83-97 \%$ ) in assessment of seizures (epilepsy) as consequence of sustained single or multiple concussions $(105,106)$.

One potential prognostic biomarker is a marked increase in the level of NR2 antibodies. These increased levels are evidence of persistent brain changes related to delayed cerebral ischemia (107), which can follow concussion. In three subjects with prior concussion, NR2 antibody levels remained elevated beyond the cut-off $(2.0 \mathrm{ng} / \mathrm{mL})$ throughout the 1.5 -year study duration (2). Interestingly, visual memory composite scores on ImPACT were impaired in two of the three athletes. Furthermore, reduction in NR2 peptide and antibodies threshold levels corresponded with improvement on ImPACT scores and reduction of postconcussive symptoms.

An AMPAR peptide assay has been evaluated as a tool for management and decision making for return to play, work, and active military duty following concussion. In a longitudinal study, initial assessment of AMPAR peptide in athletes showed that of 84 subjects $(20.8 \pm 1.8$ years old, $56 \mathrm{M} / 28 \mathrm{~F}, 1-2$ weeks post-concussion, GCS = 14-15), 18 (21\%) had increased biomarker levels after concussion (108). In the subsequent 15 months, AMPAR peptide values decreased in 11 of the 18 subjects (61\%), with levels close to normal $(0.07-0.9 \mathrm{ng} / \mathrm{mL})$. These athletes also had 
normal ImPACT scores, and were allowed to return to play. After an additional 3 months, the seven remaining athletes remained symptomatic and had higher AMPAR peptide values compared to controls. Consequently, they were advised to postpone their return to playing sports and directed to neuroimaging (2).

A recent prospective off-season study assessed AMPAR peptide levels in a professional American football team. Among players $(43 \mathrm{M}, 27.8 \pm 3.1)$ who had no concussions reported in the prior season, AMPAR peptide levels in plasma (within $0.1-1.0 \mathrm{ng} / \mathrm{mL}$ ) cleared 40 players (93\%) to play. The remaining three players $(7 \%)$ were advised to postpone return to play due to higher AMPAR peptide levels (1.2-2.3 ng/mL). Interestingly, two out of the three players with elevated AMPAR peptide levels reported concussion a week before blood draw, suggesting a cumulative effect. Preliminary assessment of assay performance characteristics in semi-acute (within 2 weeks after the concussion) assessment yielded an $89 \%$ sensitivity and $91 \%$ specificity (unpublished data).

\section{Impaired Neuroplasticity Biomarkers for Concussion (Acute and Chronic Conditions)}

Due to breakdown of the $\mathrm{BBB}$, most proteins responsible for impaired neuroplasticity enter the bloodstream, fluids, and tissues relatively late (109). Among these are the calpain-derived $\alpha I I$-spectrin N-terminal fragment (SNTF) $(78,110), \alpha I I$-spectrin breakdown products (SBDPs) for axonal injury (111), S100 associated with compromised BBB (112), astrocyte-specific protein glial fibrillary acidic protein (GFAP), a biomarker of hematoma/ hemorrhage (113) and GFAP autoantibody as a post-injury autoimmune response (80), tau protein, a microtubule-associated structural protein located within axons, and ubiquitin carboxyterminal hydrolase L1 (UCHL1), a cysteine protease expressed in neurons as well as neuroendocrine cells (114) (Table 3).

Following TBI, SNTF accumulates in axons and blood. In a study of patients with mTBI admitted to an emergency room, blood SNTF levels correlated with white matter abnormalities on DTI, as well as cognitive dysfunction and persisted for at least 3 months (110). Among professional ice hockey players, serum SNTF increased at $1 \mathrm{~h}$ after concussion and remained significantly elevated from $12 \mathrm{~h}$ to 6 days, before declining to preseason baseline. By contrast, serum SNTF levels were unchanged after training in healthy controls (78). Serum SNTF exhibited sufficient diagnostic accuracy for delayed return to play in this study (area under the curve $=0.87$ ).

S100 proteins are small acidic proteins with diverse functions that range from cell cycle progression, transcription protection from oxidative cell damage, and apoptosis $(115,116)$. A study of collegiate and semi-professional athletes who completed S100B testing at baseline and following concussion demonstrated that relative and absolute increase in serum S100B could accurately distinguish concussion from sport-related exertion (82). A correlation between S100B levels and number of sub-concussive head hits has also been reported (117). Other studies have suggested that low levels of S100B were able to rule out mTBI $(118,119)$. Recent studies have demonstrated that measurement of S100B would assist in indicating if a CT scan would be needed in the acute setting (120-122). The transient disruption of the $\mathrm{BBB}$ from multiple sub-concussive and/or concussive events may allow accumulation of S100B autoantibodies that could be associated with predisposition to neurological disease, including chronic traumatic encephalopathy (CTE). Despite prolonged rest, repetitive head impacts sustained in contact sports have been shown to cause persistent white matter alterations (123). Thus, S100B autoantibodies may be useful biomarker after acute concussion and in evaluating more chronic consequences of head trauma.

Two studies have shown that serum GFAP and its breakdown products (GFAP-BDP), markers of hemorrhage, were increased in patients with an abnormal CT compared to those with a normal CT after mTBI $(124,125)$. GFAP remained elevated in axonal injury on MRI in a subset of mTBI patients at 3 months' post-injury (124). Similarly, serum GFAP-BDP was significantly higher in patients with intracranial lesions on CT, compared with those without lesions, and was able to predict which patients required neurosurgical intervention (113). A recent study of 396 patients with mild-to-moderate TBI established that GFAP out-performed S100B in detecting intracranial CT lesions, particularly in the setting of extracranial fractures (126). GFAP-BDP demonstrated very good predictive ability $(\mathrm{AUC}=0.87)$ as well as significant discrimination of injury severity (125). Recent study detecting GFAP autoantibodies found three to five times higher biomarker values in chronic and acute cases accompanies with prior TBI (80). However, it is unclear if serum GFAP would be useful in detecting a more mild form of TBI, such as a sportsrelated concussion.

Ubiquitin carboxy-terminal hydrolase L1 levels in CSF and serum demonstrated predictive value for severe TBI in adult and children $(127,128)$ and were also increased after seizures (129). It was suggested that UCHL1 is potentially reporting the BBB integrity (94). Assessments of UCH-L1 after sport-related subconcussive head hits displayed lack of clinical significance (117).

Tau protein is a microtubule-associated structural protein located within axons. The deposition of hyperphosphorylated tau (p-tau) protein in clusters around small blood vessels of the cortex is indicative of tauopathy and is related to CTE (130). Although the factors that contribute to CTE are poorly understood, both professional athletes (131) and military veterans (132) have been diagnosed with this disease. To date, CTE is primarily diagnosed postmortem (133); however, the first attempt to detect total tau protein in plasma using digital array technology (Table 3) has recently been reported (83).

\section{DISCUSSION}

Clinical assessment tools for concussion all represent functional biomarkers. These include symptom report, neurocognitive testing, and postural stability/vestibular and oculomotor assessments. While widely used to guide clinical care, concern regarding the sensitivity of these functional biomarkers as well as their feasibility for use in the sports arena exists. For example, sideline testing is brief and, therefore, may not be sensitive enough to identify mild concussion. Comprehensive neurocognitive 
TABLE 4 | Proposed functional, metabolic, and structural biomarkers to assess severity of acute concussions and mTBI.

\begin{tabular}{|c|c|c|c|c|c|c|c|}
\hline \multirow[t]{3}{*}{ Neuroanatomical area of injury } & \multicolumn{3}{|c|}{$\begin{array}{l}\text { Clinical and Neuropsychological } \\
\text { scores }\end{array}$} & \multirow[t]{3}{*}{$\begin{array}{l}\text { Neurotoxicity } \\
\text { markers }^{c}\end{array}$} & \multicolumn{3}{|c|}{ Proposed scores } \\
\hline & \multirow[t]{2}{*}{ GCS } & \multirow[t]{2}{*}{ ImPACT ${ }^{a}$} & \multirow[t]{2}{*}{ SCAT3 $^{b}$} & & \multicolumn{2}{|c|}{ 3T (or higher) MRI } & \multirow[t]{2}{*}{ GCS/MRI/biomarkers } \\
\hline & & & & & Preferable modality & Scores & \\
\hline Subcortical dendritic-axonal injury (DAl) & 15 & $0.3-0.4$ & 19.3 & $\operatorname{AMPAR}(\mathrm{A})$ & DTI & 1 & $15 \mathrm{~A} 1$ \\
\hline $\begin{array}{l}\text { Cortical-subcortical, subcortical-cervical } \\
\text { area, or cortical-cervical area, transient } \\
\text { events (vasogenic edema) }\end{array}$ & 14 & $0.2-0.3$ & 40.7 & $\begin{array}{l}\operatorname{AMPAR}(\mathrm{A}) \mathrm{NR} 2(\mathrm{~N}) \\
\operatorname{KAR}(\mathrm{K})\end{array}$ & DWI, DTI & 2 & $\begin{array}{l}14 \text { AN2 -cortical } \\
\text { - subcortical } \\
\text { 14AK2 - subcortical } \\
\text {-cervical } \\
\text { 14NK2- cortical-cervical }\end{array}$ \\
\hline $\begin{array}{l}\text { Cortical-subcortical and cervical area } \\
\text { (cytotoxic edema) }\end{array}$ & $12-13$ & $0.1-0.2$ & 46.2 & $\begin{array}{l}\text { Overall involvement of } \\
\text { ionotropic GluRs ANK }\end{array}$ & $\begin{array}{l}\text { FLAIR, SWI/SWAN, } \\
\text { DTI }\end{array}$ & 3 & $\begin{array}{l}\text { 12ANK3 } \\
13 \mathrm{ANK} 3\end{array}$ \\
\hline
\end{tabular}

${ }^{a}$ Considered only cognitive efficacy score.

SSCAT3 data were considered from (21).

'Considered only abnormal values of AMPAR, AMPA receptor peptide fragment (candidate biomarker of DAl); NR2, peptide fragment of NMDA receptor subtype (arterial

microvascular marker candidate); KAR, kainite receptor peptide fragment (venous circulation biomarker candidate).

${ }^{\circ} \mathrm{MRI}$ scores are suggested analog to that proposed by Potapov et al. (71) based on location/level of brain lesions for TBI.

testing may appear normal, leading to premature return to play. More objective means of assessment, including advanced neuroimaging techniques and neurotoxicity biomarkers, have gained research attention. These measures may facilitate diagnosis and potentially assist with monitoring a subject's recovery. Preliminary studies suggest neurotoxicity biomarkers, in conjunction with neurocognitive testing, may improve diagnostic certainty of suspected concussions as well as provide valuable information on prognosis, allowing a clinician to modify treatment recommendations.

This review highlights potential structural and neurotoxicity biomarkers that could be integrated into the current clinical concussion evaluation that, at present, relies primarily on functional biomarkers. Research to date supports a move toward administering a more comprehensive panel of biomarkers; namely, neurotoxicity markers. These biomarkers represent a second generation of brain "tracers" that could be used to decipher the microstructural abnormalities observed on advanced neuroimaging. For example, abnormal values of one (15A1), two (14AN2, 14NK2, 14 AK2), or three GluRs (12-13ANK3) may assist in making a decision to return a subject to play, extended rest, or further medical assistance (Table 4). Those athletes or patients with abnormal scores using these biomarkers should be directed to neuroimaging assessment (DTI, DWI, SWI, FLAIR), and may benefit from an individualized treatment plan. In the future, it may be possible to classify concussion severity with neuroimaging, similar to proposed MRI classification for TBI (71). Furthermore, the use of neurotoxicity biomarkers may assist radiologists with additional information concerning the area of interest, where microstructural changes might be located (cortical, subcortical, or brainstem injuries).

Accurate diagnosis of concussion and appropriate management of the injury to prevent premature return to play is vital to protecting the long-term brain health of athletes and others at risk of re-injury. Structural and neurotoxicity biomarkers can be used to complement the functional biomarkers currently used to assess concussion to facilitate diagnosis and treatment.

\section{HUMAN SUBJECTS}

This review presents retrospective analyses of neurotoxicity biomarkers measured in subjects with concussions and mild TBI previously disclosed in peer-reviewed scientific publications.

All retrospective analyses of human data concerning GluR biomarker studies conducted by the authors were performed in accordance with institutional and national guidelines and regulations. The institutional review protocol governing the college and professional athletes' enrollment was approved by the respective Institutional Review Boards at Kennesaw State University, the University of Pittsburgh, and by the USAMRMC ORP HRPO under proposal DM090557 (award W81XWH-11-2-0081). The research protocol for using samples collected from active duty personnel and civilians who suffered mild TBI in the studies described herein were approved by the Ethics Committee at Burdenko Institute of Neurosurgery (Moscow, Russia). Written informed consent was provided by all research subjects. The privacy of participants was protected using global unique identifiers.

\section{AUTHOR CONTRIBUTIONS}

SD and JDM are joint senior authors. AMS, JDM, EVA, and AAP are contributed equally to this work.

\section{FUNDING}

In parts supported by grant from US Army Medical Research and Materiel Command, 2011-2013 and grant from Skolkovo BioMed, Moscow, Russia, 2016-2017. 


\section{REFERENCES}

1. Collins MW, Kontos AP, Reynolds E, Murawski CD, Fu FH. A comprehensive, targeted approach to the clinical care of athletes following sport-related concussion. Knee Surg Sports Traumatol Arthrosc (2014) 22:235-46. doi:10.1007/ s00167-013-2791-6

2. Dambinova SA, Sowell RL, Maroon J. Gradual return to play: potential role of neurotoxicity biomarkers in assessment of concussions severity. J Mol Biomark Diagn (2013) 3(Suppl1):S003. doi:10.4172/2155-9929.S3-003

3. Lebrun CM, Mrazik M, Prasad AS, Tjarks BJ, Dorman JC, Bergeron MF, et al. Sport concussion knowledge base, clinical practises and needs for continuing medical education: a survey of family physicians and cross-border comparison. Br J Sports Med (2012) 47:54-9. doi:10.1136/bjsports-2012-091480

4. Zehtabchi S, Sinert R, Soghoian S, Liu Y, Carmody K, Shah L, et al. Identifying traumatic brain injury in patients with isolated head trauma: are arterial lactate and base deficit as helpful as in polytrauma? Emerg Med J (2007) 24:333-5. doi:10.1136/emj.2006.044578

5. Dambinova SA, Bettermann K, Glynn T, Tews M, Olson D, Weissman JD, et al. Diagnostic potential of the NMDA receptor peptide assay for acute ischemic stroke. PLoS One (2012) 7:e42362. doi:10.1371/journal.pone.0042362

6. McCrory P, Meeuwisse WH, Aubry M, Cantu B, Dvorák J, Echemendia RJ, et al. Consensus statement on concussion in sport: the 4th International Conference on Concussion in Sport held in Zurich. Br J Sports Med (2013) 47:250-8. doi:10.1136/bjsports-2013-092313

7. Blennow K, Hardy J, Zetterberg H. The neuropathology and neurobiology of traumatic brain injury. Neuron (2012) 76:886-99. doi:10.1016/ j.neuron.2012.11.021

8. Choe MC, Babikian T, DiFiori J, Hovda DA, Giza CC. A pediatric perspective on concussion pathophysiology. Curr Opin Pediatr (2012) 24:689-95. doi:10.1097/MOP

9. Khurana VG, Kaye AH. An overview of concussion in sport. J Clin Neurosci (2012) 19:1-11. doi:10.1016/j.jocn.2011.08.002

10. Guskiewicz KM, Mihalik JP. Biomechanics of sport concussion: quest for the elusive injury threshold. Exerc Sport Sci Rev (2011) 39:4-11. doi:10.1097/ JES.0b013e318201f53e

11. Johnston SC, Albers GW, Gorelick PB, Cumbler E, Klingman J, Ross MA, et al. National Stroke Association recommendations for systems of care for transient ischemic attack. Ann Neurol (2011) 69:872-7. doi:10.1002/ ana.22332

12. King D, Hume P, Gissane C, Brughelli M, Clark T. The influence of head impact threshold for reporting data in contact and collision sports: systematic review and original data analysis. Sports Med (2016) 46:151-69. doi:10.1007/ s40279-015-0423-7

13. Bailes JE, Petralia AL, Omalu BI, Nauman E, Talavage T. Role of subconcussion in repetitive mild traumatic brain injury. J Neurosurg (2013) 119:1235-45. doi:10.3171/2013.7.JNS121822

14. Rezaei A, Karami G, Ziejewski M. Examination of brain Injury thresholds in terms of the severity of head motion and the brain stresses. Intern Neurotrauma Lett (2014) 35. Available from: http://www.internationalbrain. org/examination-of-bi-thresholds-in-terms-of-the-severity-of-headmotion-and-the-brain-stresses/

15. Okonkwo DO, Tempel ZJ, Maroon J. Sideline assessment tools for the evaluation of concussion in athletes: a review. Neurosurg (2014) 75(Suppl 4):S82-95. doi:10.1227/NEU.0000000000000493

16. Kutcher JS, McCrory P, Davis G, Ptito A, Meeuwisse WH, Broglio SP. What evidence exists for new strategies or technologies in the diagnosis of sports concussion and assessment of recovery? Br J Sports Med (2013) 47:299-303. doi:10.1136/bjsports-2013-092257

17. Breedlove EL, Robinson M, Talavage TM, Morigaki KE, Yoruk U, O’Keefe K, et al. Biomechanical correlates of symptomatic and asymptomatic neurophysiological impairment in high school football. J Biomech (2012) 45:1265-72. doi:10.1016/j.jbiomech.2012.01.034

18. Chen Y, Peng Y, Li F, Yang JK, Otte D. Brain injury for vulnerable road users in vehicle accidents using mathematical models. In: Lim CT, Goh JCH, editors. IFMBE Proceedings WCB 2010, 6th World Congress of Biomechanics (WCB 2010) (Vol. 31), Singapore, Malaysia: Springer (2010). p. 497-500.

19. Guskiewicz KM, Mihalik JP, Shankar V, Marshall SW, Crowell DH, Oliaro SM, et al. Measurement of head impacts in collegiate football players: relationship between head impact biomechanics and acute clinical outcome after concussion. Neurosurg (2007) 61:1244-52. doi:10.1227/ 01.neu.0000306103.68635.1a

20. Zhang L, Yang KY, King AI. A proposed injury threshold for mild traumatic brain injury. J Biomech Eng (2004) 126:226-36. doi:10.1115/1.1691446

21. Guskiewicz KM, Register-Mihalik J, McCrory P, McCrea M, Johnston K, Makdissi M, et al. Evidence-based approach to revising the SCAT2: introducing the SCAT3. Br J Sports Med (2013) 47:289-93. doi:10.1136/ bjsports-2013-092225

22. Kontos AP, Sufrinko A, Womble M, Kegel N. Neuropsychological assessment following concussion: an evidence-based review of the role of neuropsychological assessment pre-and post-concussion. Curr Pain Headache Rep (2016) 20:38. doi:10.1007/s11916-016-0571-y

23. Resch J, McCrea M, Cullum CM. Computerized neurocognitive testing in the management of sport-related concussion: an update. Neuropsychol Rev (2013) 23:335-49. doi:10.1007/s11065-013-9242-5

24. Coldren RL, Russell ML, Parish RV, Dretsch M, Kelly MP. The ANAM lacks utility as a diagnostic or screening tool for concussion more than 10 days following injury. Mil Med (2012) 177:179-83. doi:10.7205/ MILMED-D-11-00278

25. Guskiewicz KM. Assessment of postural stability following sport-related concussion. Curr Sports Med Rep (2003) 2:24-30. doi:10.1249/00149619-200302000-00006

26. Valovich TC, Perrin DH, Gansneder BM. Repeat administration elicits a practice effect with the balance error scoring system but not with the Standardized Assessment of Concussion in high school athletes. J Athl Train (2003) 38:51-6.

27. Broglio SP, Ferrara MS, Sopiarz K, Kelly MS. Reliable change of the sensory organization test. Clin J Sport Med (2008) 18:148-54. doi:10.1097/ JSM.0b013e318164f42a

28. Mucha A, Collins MW, Elbin RJ, Furman JM, Troutman-Enseki C, DeWolf RM, et al. A brief vestibular/ocular motor screening (VOMS) assessment to evaluate concussions: preliminary findings. Am J Sports Med (2014) 42:2479-86. doi:10.1177/0363546514543775

29. Samadani U, Ritlop R, Reyes M, Nehrbass E, Li M, Lamm E, et al. Eye tracking detects disconjugate eye movements associated with structural traumatic brain injury and concussion. J Neurotrauma (2015) 32:548-56. doi:10.1089/ neu. 2014.3687

30. King D, Brughelli M, Hume P, Gissane C. Concussions in amateur rugby union identified with the use of a rapid visual screening tool. J Neurol Sci (2013) 326:59-63. doi:10.1016/j.jns.2013.01.012

31. Echemendia RJ, Iverson GL, McCrea M, Macciocchi SN, Gioia GA, Putukian $\mathrm{M}$, et al. Advances in neuropsychological assessment of sport-related concussion. Br J Sports Med (2013) 47:294-8. doi:10.1136/ bjsports-2013-092186

32. Giza CC, Kutcher JS, Ashwal S, Barth J, Getchius TS, Gioia GA, et al. Summary of evidence-based guideline update: evaluation and management of concussion in sports: report of the Guideline Development Subcommittee of the American Academy of Neurology. Neurology (2013) 80:2250-7. doi:10.1212/WNL.0b013e31828d57dd

33. McLeod TC, Leach C. Psychometric properties of self-report concussion scales and checklists. J Athl Train (2012) 47:221-3.

34. McCrea M, Kelly JP, Randolph C, Kluge J, Bartolic E, Finn G, et al. Standardized assessment of concussion (SAC): on-site mental status evaluation of the athlete. JHead Trauma Rehabil (1998) 13:27-35. doi:10.1097/00001199-199804000-00005

35. Barker JM, Wright DW, Goldstein FC, Ockerman J, Ratcliff JJ, Laplaca MC. The DETECT System: portable, reduced-length neuropsychological testing for mild traumatic brain injury via a novel immersive environment. J Med Eng Technol (2007) 31:161-9. doi:10.1080/0309190050027281

36. Iverson GL, Brooks BL, Collins MW, Lovell MR. Tracking neuropsychological recovery following concussion in sport. Brain Inj (2006) 20:245-52. doi:10.1080/02699050500487910

37. McClincy MP, Lovell MR, Pardini J, Collins MW, Spore MK. Recovery from sports concussion in high school and collegiate athletes. Brain Inj (2006) 20:33-9. doi:10.1080/02699050500309817

38. Kontos AP, Braithwaite R, Dakan S, Elbin RJ. Computerized neurocognitive testing within 1 week of sport-related concussion: meta-analytic review and 
analysis of moderating factors. J Int Neuropsychol Soc (2014) 20:324-32. doi:10.1017/S1355617713001471

39. De Marco AP, Broshek DK. Computerized cognitive testing in the management of youth sports-related concussion. J Child Neurol (2016) 31:68-75. doi:10.1177/0883073814559645

40. Elbin RJ, Kontos AP, Kegel N, Johnson E, Burkhart S, Schatz P. Individual and combined effects of $\mathrm{LD}$ and ADHD on computerized neurocognitive concussion test performance: evidence for separate norms. Arch Clin Neuropsychol (2013) 28:476-84. doi:10.1093/arclin/act024

41. Furman GR, Lin C-C, Bellanca JL, Marchetti GF, Collins MW, Whitney SL. Comparison of the balance accelerometer measure and balance error scoring system in adolescent concussions in sports. Am J Sports Med (2013) 41:1404-10. doi:10.1177/0363546513484446

42. Pearce KL, Sufrinko A, Lau BC, Henry L, Collins MW, Kontos AP. Near point of convergence after a sport-related concussion: measurement reliability and relationship to neurocognitive impairment and symptoms. Am J Sports Med (2015) 43:3055-61. doi:10.1177/0363546515606430

43. Vartiainen MV, Holm A, Peltonen K, Luoto TM, Iverson G, Hokkanen L. King-Devick test normative reference values for professional male ice hockey players. Scand J Med Sci Sports (2015) 25:e327-30. doi:10.1111/sms.12307

44. Leong DF, Balcer LJ, Galetta SL, Evans G, Gimre M, Watt D. The King-Devick test for sideline concussion screening in collegiate football. J Optom (2015) 8:131-9. doi:10.1016/j.optom.2014

45. Galetta KM, Brandes LE, Maki K, Dziemianowicz MS, Laudano E, Allen M, et al. The King-Devick test and sports-related concussion: study of a rapid visual screening tool in a collegiate cohort. J Neurol Sci (2011) 309:34-9. doi:10.1016/j.jns.2011.07.039

46. Maruta J, Tong J, Lee SW, Iqbal Z, Schonberger A, Ghajar J. EYE-TRAC: monitoring attention and utility for mTBI. Proceedings SPIE 8371: Sensing Technologies for Global Health, Military Medicine, Disaster Response, and Environmental Monitoring II; and Biometric Technology for Human Identification IX, 83710L, Baltimore, Maryland (2012). doi:10.1117/12.927790

47. Mechtler LL, Dhsdtri KK, Crutchfield KE. Advanced neuroimaging of mild traumatic brain injury. Neurol Clin (2014) 32:31-58. doi:10.1016/ j.ncl.2013.08.002

48. Bigler ED. Neuroimaging biomarkers in mild traumatic brain injury (mTBI). Neuropsychol Rev (2013) 23:169-209. doi:10.1007/s11065-013-9237-2

49. Lovell MR, Pardini JE, Welling J, Collins MW, Bakal J, Lazar N, et al. Functional brain abnormalities are related to clinical recovery and time to return-to-play in athletes. Neurosurgery (2007) 61:352-9. doi:10.1227/ 01.NEU.0000279985.94168.7F

50. Kou Z, Wu Z, Tong KA, Holshouser B, Benson RR, Hu J, et al. The role of advanced MR imaging findings as biomarkers of traumatic brain injury.J Head Trauma Rehabil (2010) 25:267-82. doi:10.1097/HTR.0b013e3181e54793

51. Bartnik-Olson BL, Holshouser B, Wang H, Grube M, Tong K, Wong V, et al. Impaired neurovascular unit function contributes to persistent symptoms after concussion: a pilot study. J Neurotrauma (2014) 31:1497-506. doi:10.1089/neu.2013.3213

52. Delouche A, Attyé A, Heck O, Grand S, Kastler A, Lamalle L, et al. Diffusion MRI: pitfalls, literature review and future directions of research in mild traumatic brain injury. Eur J Radiol (2016) 85:25-30. doi:10.1016/ j.ejrad.2015.11.004

53. Chong CD, Schwedt TJ. White matter damage and brain network alterations in concussed patients: a review of recent diffusion tensor imaging and resting-state functional connectivity data. Curr Pain Headache Rep (2015) 19:485. doi:10.1007/s11916-015-0485-0

54. Wintermark M, Sanelli PC, Anzai Y, Tsiouris AJ, Whitlow CT; ACR Head Injury Institute. Imaging evidence and recommendations for traumatic brain injury: conventional neuroimaging techniques. J Am Coll Radiol (2015) 12:e1-14. doi:10.1016/j.jacr.2014.10.014

55. Dimou S, Lagopoulos J. Toward objective markers of concussion in sport: a review of white matter and neurometabolic changes in the brain after sport-related concussion. J Neurotrauma (2014) 31:413-24. doi:10.1089/ neu. 2013.3050

56. Shenton ME, Hamoda HM, Schneiderman JS, Bouix S, Pasternak O, Rathi Y, et al. A review of magnetic resonance imaging and diffusion tensor imaging findings in mild traumatic brain injury. Brain Imaging Behav (2012) 6:137-92. doi:10.1007/s11682-012-9156-5
57. McAllister TW, Ford JC, Ji S, Beckwith JG, Flashman LA, Paulsen K, et al. Maximum principal strain and strain rate associated with concussion diagnosis correlates with changes in corpus callosum white matter indices. Ann Biomed Eng (2012) 40:127-40. doi:10.1007/s10439-011-0402-6

58. Henry LC, Tremblay J, Tremblay S, Lee A, Brun C, Lepore N, et al. Acute and chronic changes in diffusivity measures after sports concussion. J Neurotrauma (2011) 28:2049-59. doi:10.1089/neu.2011.1836

59. Lipton ML, Kim N, Zimmerman ME, Kim M, Stewart WF, Branch CA, et al. Soccer heading is associated with white matter microstructural and cognitive abnormalities. Radiology (2013) 268:850-7. doi:10.1148/radiol.13130545

60. Davenport EM, Apkarian K, Whitlow CT, Urban JE, Jensen JH, Szuch E, et al. Abnormalities in diffusional kurtosis metrics related to head impact exposure in a season of high school varsity football. J Neurotrauma (2016). doi:10.1089/neu.2015.4267

61. Huisman TA, Sorensen AG, Hergan K, Gonzalez RG, Schaefer PW. Diffusion-weighted imaging for the evaluation of diffuse axonal injury in closed head injury. J Comput Assist Tomogr (2003) 27:5-11. doi:10.1097/00004728-200301000-00002

62. Ellis MJ, Ryner LN, Sobszyk O, Fierstra J, Mikulis DJ, Fisher JA, et al. Neuroimaging assessment of cerebrovascular reactivity in concussion: current concepts, methodological considerations, and review of the literature. Front Neurol (2016) 7:61. doi:10.3389/fneur.2016.00061

63. Casson IR, Viano DC, Haacke EM, Kou Z, LeStrange DG. Is there chronic brain damage in retired NFL players? neuroradiology, neuropsychology, and neurology examinations of 45 retired players. Sports Health (2014) 6:384-95. doi: $10.1177 / 1941738114540270$

64. Ellis MJ, Leiter J, Hall T, McDonald PJ, Sawyer S, Silver N, et al. Neuroimaging findings in pediatric sports-related concussion. J Neurosurg Pediatr (2015) 16:241-7. doi:10.3171/2015.1.PEDS14510

65. Hasiloglu ZI, Albayram S, Selcuk H, Ceyhan E, Delil S, Arkan B, et al. Cerebral microhemorrhages detected by susceptibility-weighted imaging in amateur boxers. AJNR Am J Neuroradiol (2011) 32:99-102. doi:10.3174/ajnr. A2250

66. Helmer KG, Pasternak O, Fredman E, Preciado RI, Koerte IK, Sasaki T, et al. Hockey concussion education project, part 1. Susceptibility-weighted imaging study in male and female ice hockey players over a single season. J Neurosurg (2014) 120:864-72. doi:10.3171/2013.12.JNS132093

67. Liu C, Li W, Tong KA, Yeom KW, Kuzminski S. Susceptibility-weighted imaging and quantitative susceptibility mapping in the brain. J Magn Reson Imaging (2015) 42:23-41. doi:10.1002/jmri.24768

68. Docampo J, Gonzalez N, Bravo F, Sarroca D, Morales C, Bruno C. Susceptibility-weighted angiography of intracranial blood products and calcifications compared to gradient echo sequence. Neuroradiol. J (2013) 26:493-500. doi:10.1177/197140091302600501

69. Patzig M, Feddersen B, Haegler K, Olzowy B, Mees K, Fischer R, et al. Susceptibility-weighted angiography visualizes hypoxia in cerebral veins. Invest Radiol (2015) 50:397-400. doi:10.1097/RLI.0000000000000143

70. Hayashida Y, Kakeda S, Hiai S, Ide S, Ogasawara A, Ooki H, et al. Diagnosis of intracranial hemorrhagic lesions: comparison between 3D-SWAN (3D $\mathrm{T} 2{ }^{*}$-weighted imaging with multi-echo acquisition) and $2 \mathrm{D}$-T2*-weighted imaging. Acta Radiol (2014) 55:201-7. doi:10.1177/0284185113495836

71. Potapov AA, Zarharova NE, Kornienko VN, Pronin IN, Alexandrova EV, Zaitsev OS, et al. Neuroanatomical foundations for traumatic coma: clinical and magnetic resonance correlates. Zh Vopr Neirokhir Im N N Burdenko (2014) 78:4-13.

72. Zakharova N, Kornienko V, Potapov A, Pronin I. Neuroimaging of Traumatic Brain Injury. Heidelberg: Springer (2014). p. 35-68.

73. Doshi H, Wiseman N, Liu J, Wang W, Welch RD, O’Neil BJ, et al. Cerebral hemodynamic changes of mild traumatic brain injury at the acute stage. PLoS One (2015) 10:e0118061. doi:10.1371/journal.pone.0118061

74. Gardner A, Iverson GL, Stanwell P. A systematic review of proton magnetic resonance spectroscopy findings in sport-related concussion. J Neurotrauma (2014) 31:1-18. doi:10.1089/neu.2013.3079

75. Sahu P, Pinkalwar N, Dubey RD, Rapoha S, Chatterjee S, Chatterjee T. Biomarkers: an emerging tool for diagnosis of a disease and drug development. Asian J Res Pharm Sci (2011) 1:9-16.

76. Henry NL, Hayes DF. Cancer biomarkers. Mol Oncol (2012) 6:140-6. doi:10.1016/j.molonc.2012.01.010 
77. Ashby MC, Daw MI, Issac JTR. AMPA Receptors. In: Gereau RW IV, Swanson GT, editors. The Glutamate Receptors. Totowa: Humana Press (2008). p. 1-44.

78. Siman R, Shahim P, Tegner Y, Blennow K, Zetterberg H, Smith DH. Serum SNTF increases in concussed professional ice hockey players and relates to the severity of postconcussion symptoms. J Neurotrauma (2015) 32:1294-300. doi:10.1089/neu.2014.3698

79. Papa L, Brophy GM, Welch RD, Lewis LM, Braga CF, Tan CN, et al. Time course and diagnostic accuracy of glial and neuronal blood biomarkers GFAP and UCH-L1 in a large cohort of trauma patients with and without mild traumatic brain injury. JAMA Neurol (2016) 73:551-60. doi:10.1001/ jamaneurol.2016.0039

80. Wang KK, Yang Z, Yue JK, Zhang Z, Winkler EA, Puccio AM, et al. Plasma anti-glial fibrillary acidic protein autoantibody levels during the acute and chronic phases of traumatic brain injury: a transforming research and clinical knowledge in traumatic brain injury pilot study. J Neurotrauma (2016) 33:1270-7. doi:10.1089/neu.2015.3881

81. Dambinova SA. Neurodegradomics: the source of biomarkers for mild TBI. In: Dambinova SA, Hayes RL, Wang KKW, editors. Biomarkers for TBI. London, UK: RSC Publishing, RSC Drug Discovery Series (2012). p. 66-86.

82. Kiechle K, Bazarian JJ, Merchant-Borna K, Stoecklein V, Rozen E, Blyth B, et al. Subject-specific increases in serum S-100B distinguish sports-related concussion from sports-related exertion. PLoS One (2014) 9:e84977. doi:10.1371/journal.pone.0084977

83. Shahim P, Tegner Y, Wilson DH, Randall J, Skillbäck T, Pazooki D, et al. Blood biomarkers for brain injury in concussed professional ice hockey players. JAMA Neurol (2014) 71:684-92. doi:10.1001/jamaneurol.2014.367

84. Posti JP, Takala RS, Runtti H, Newcombe VF, Outtrim J, Katila AJ, et al. The levels of glial fibrillary acidic protein and ubiquitin C-terminal hydrolase-L1 during the first week after a traumatic brain injury: correlations with clinical and imaging findings. Neurosurgery (2016) 79:456-64. doi:10.1227/ NEU.0000000000001226

85. Takala RS, Posti JP, Runtti H, Newcombe VF, Outtrim J, Katila AJ, et al. Glial fibrillary acidic protein and ubiquitin C-terminal hydrolase-L1 as outcome predictors in traumatic brain injury. World Neurosurg (2016) 87:8-20. doi:10.1016/j.wneu.2015.10.066

86. Dambinova SA, Shikuev AV, Weissman JD, Mullins JD. AMPAR peptide values in blood of nonathletes and club sport athletes with concussions. Mil Med (2013) 3:285-90. doi:10.7205/MILMED-D-12-00368

87. Hammond JC, McCullumsmith RE, Funk AJ, Haroutunian V, MeadorWoodruff $\mathrm{JH}$. Evidence for abnormal forward trafficking of AMPA receptors in frontal cortex of elderly patients with schizophrenia. Neuropsychopharmacology (2010) 35:2110-9. doi:10.1038/npp.2010.87

88. Lai M, Hughes EG, Peng X, Zhou L, Gleichman AJ, Shu H, et al. AMPA receptor antibodies in limbic encephalitis alter synaptic receptor location. Ann Neurol (2009) 65:424-34. doi:10.1002/ana.21589

89. Shrey DW, Griesbach GS, Giza CC. The pathophysiology of concussions in youth. Phys Med Rehabil Clin N Am (2011) 22:577-602. doi:10.1016/ j.pmr.2011.08.002

90. Sharp CD, Fowler M, Jackson TH, Houghton J, Warren A, Nanda A, et al. Human neuroepithelial cells express NMDA receptors. BMC Neurosci (2003) 4:28. doi:10.1186/1471-2202-4-28

91. Danilenko UD, Khunteev GA, Bagumyan A, Izykenova GA. Neurotoxicity biomarkers in experimental acute and chronic brain injury. In: Dambinova SA, Hayes RL, Wang KKW, editors. Biomarkers for TBI. London, UK: RSC Publishing, RSC Drug Discovery Series (2012). p. 87-98.

92. Jin XT, Smith Y. Localization and functions of kainate receptors in the basal ganglia. In: Rodriguez-Moreno A, Sihra TS, editors. Kainate Receptors. New York: Springer (2011). p. 27-37.

93. Alexandrova EV, Zaitsev OS, Potapov AA. Neurotransmitter basis of consciousness and unconsciousness states. Zh Vopr Neirokhir Im NN Burdenko (2014) 78:26-32.

94. Blyth BJ, Farhavar A, Gee C, Hawthorn B, He H, Nayak A, et al. Validation of serum markers for blood-brain barrier disruption in traumatic brain injury. J Neurotrauma (2009) 26:1497-507. doi:10.1089/neu.2008-0738

95. Engelhardt B, Ransohoff RM. The ins and outs of T-lymphocyte trafficking to the CNS: anatomical sites and molecular mechanisms. Trends Immunol (2005) 26:485-95. doi:10.1016/j.it.2005.07.004
96. Vincent A, Bien CG, Irani SR, Waters P. Autoantibodies associated with diseases of the CNS: new developments and future challenges. Lancet Neurol (2011) 10:759-72. doi:10.1016/S1474-4422(11)70096-5

97. Raad M, Nohra E, Chams N, Itani M, Talih F, Mondello S, et al. Autoantibodies in traumatic brain injury and central nervous system trauma. Neuroscience (2014) 281:16-23. doi:10.1016/j.neuroscience.2014.08.045

98. Blaylock RL, Maroon JC. Imminoexcitotoxicity as a central mechanism in chronic traumatic encephalopathy - A unifying hypothesis. In: Dambinova SA, Hayes RL, Wang KKW, editors. Biomarkers for TBI. London, UK: RSC Publishing, RSC Drug Discovery Series (2012). p. 45-65.

99. Weissman JD, Khunteev GA, Heath R, Dambinova SA. NR2 antibodies: risk assessment of transient ischemic attack (TIA)/stroke in patients with history of isolated and multiple cerebrovascular events. J Neurol Sci (2011) 300:97-102. doi:10.1016/j.jns.2010.09.023

100. Nasser M, Bejjani F, Raad M, El Hassan HA, Mantash S, Nokkari A, et al. Traumatic brain injury and blood brain barrier cross talk. CNS Neurol Disord Drug Targets (2016) 15:1. doi:10.2174/1871527315666160815093525

101. Dambinova SA. Biomarkers for transient ischemic attack (TIA) and ischemic stroke. Clin Lab Int (2008) 32:7-11.

102. Dambinova SA, Izykenova GA, Burov SV, Grigorenko EV, Gromov SA. The presence of autoantibodies to N-terminus domain of GluR1 subunit of AMPA receptor in the blood serum of patients with epilepsy. J Neurol Sci (1997) 152:93-7. doi:10.1016/S0022-510X(97)00150-0

103. Dambinova SA, Granstrem OK, Tourov A, Salluzzo R, Castello F, Izykenova GA. Monitoring of brain spiking activity and autoantibodies to $\mathrm{N}$-terminus domain of GluR1 subunit of AMPA receptors in blood serum of rats with cobalt-induced epilepsy. J Neurochem (1998) 71:2088-93. doi:10.1046/j.1471-4159.1998.71052088.x

104. Goryunova AV, Bazarnaya NA, Sorokina EG, Semenova NY, Globa OV, Semenova $\mathrm{ZhB}$, et al. Glutamate receptor antibody concentrations in children with chronic post-traumatic headache. Neurosci Behav Physiol (2007) 37:761-4. doi:10.1007/s11055-007-0079-3

105. Mullins JD, Shikuev AV, Danilenko UI, Dambinova SA. AMPAR Peptide values in sport-related concussions. In: 2012 Military Health System Research Symposium; 2012 Aug 13-16. Ft. Lauderdale: USAMRMC (2012). p. 134.

106. Mullins JD. Biomarkers of TBI: implications for diagnosis and management of contusions. AMSUS 118 th Annual Continuing Education Meeting; 2013 Nov 3-8. Seattle, WA (2013). 147 p. Available from: http://amsusce.org/ wp-content/uploads/2015/05/Abstract-Summaries-10.22.13.2.pdf

107. Sorokina EG, Semenova ZhB, Bazarnaya NA, Meshcheryakov SV, Reutov VP, Goryunova AV, et al. Autoantibodies to glutamate receptors and products of nitric oxide metabolism in serum in children in the acute phase of craniocerebral trauma. Neurosci Behav Physiol (2009) 39:329-34. doi:10.1007/ s11055-009-9147-1

108. Dambinova SA, Gill S, St. Onge L, Sowell RL. Biomarkers for subtle brain dysfunction. In: Dambinova SA, Hayes RL, Wang KKW, editors. Biomarkers for TBI. London, UK: RSC Publishing, RSC Drug Discovery Series (2012). p. 134-47.

109. Nag S, Kapadia A, Stewart DJ. Review: molecular pathogenesis of bloodbrain barrier breakdown in acute brain injury. Neuropathol Appl Neurobiol (2011) 37:3-23. doi:10.1111/j.1365-2990.2010.01138.x

110. Siman R, Giovannone N, Hanten G, Wilde EA, McCauley SR, Hunter JV, et al. Evidence that the blood biomarker SNTF predicts brain imaging changes and persistent cognitive dysfunction in mild TBI patients. Front Neurol (2013) 4:190. doi:10.3389/fneur.2013.00190

111. Berger RP, Hayes RL, Richichi R, Beers SR, Wang KK. Serum concentrations of ubiquitin C-terminal hydrolase-L1 and $\alpha$ II-spectrin breakdown product $145 \mathrm{kDa}$ correlate with outcome after pediatric TBI. J Neurotrauma (2012) 29:162-7. doi:10.1089/neu.2011

112. Koh SX, Lee JK. S100B as a marker for brain damage and blood-brain barrier disruption following exercise. Sports Med (2014) 44:369-85. doi:10.1007/ s40279-013-0119-9

113. Papa L, Lewis LM, Falk JL, Zhang Z, Silvestri S, Giordano P, et al. Elevated levels of serum glial fibrillary acidic protein breakdown products in mild and moderate traumatic brain injury are associated with intracranial lesions and neurosurgical intervention. Ann Emerg Med (2012) 59:471-83. doi:10.1016/j. annemergmed.2011.08.021

114. Jaber Z, Aouad P, Al Medawar M, Bahmad H, Abou-Abbass H, Ghandour $\mathrm{H}$, et al. Role of systems biology in brain injury biomarker discovery: 
neuroproteomics application. In: Kobeissy F, Dixon CE, Hayes RL, Mondello S, editors. Injury Models of the Central Nervous System (Vol. 1462). New York: Humana Press, Methods Mol Biol Series (2016). p. 157-74.

115. Sedaghat F, Notopoulos A. S100 protein family and its application in clinical practice. Hippokratia (2008) 12:198-204.

116. Steiner J, Bernstein H-G, Bielau H, Berndt A, Brisch R, Mawrin C, et al. Evidence for a wide extra-astrocytic distribution of S100B in human brain. BMC Neurosci (2007) 8:2. doi:10.1186/1471-2202-8-2

117. Puvenna V, Brennan C, Shaw G, Yang C, Marchi N, Bazarian JJ, et al. Significance of ubiquitin carboxy-terminal hydrolase L1 elevations in athletes after sub-concussive head hits. PLoS One (2014) 9:e96296. doi:10.1371/ journal.pone.0096296

118. Zongo D, Ribereau-Gayon R, Masson F, Laborey M, Contrand B, Salmi LR, et al. S100-B protein as a screening tool for the early assessment of minor head injury. Ann Emerg Med (2012) 59:209-18. doi:10.1016/ j.annemergmed.2011.07.027

119. Dorminy M, Hoogeveen A, Tierney RT, Higgins M, McDevitt JK, Kretzschmar J. Effect of soccer heading ball speed on S100B, sideline concussion assessments and head impact kinematics. Brain Inj (2015) 29:1158-64. doi:10.3109/02699052.2015.1035324

120. Hansen-Schwartz J, Bouchelouche PN. Use of biomarker S100B for traumatic brain damage in the emergency department may change observation strategy. Dan Med J (2014) 61:A4894.

121. Laribi S, Kansao J, Borderie D, Collet C, Deschamps P, Ababsa R, et al. S100B blood level measurement to exclude cerebral lesions after minor head injury: the multicenter STIC-S100 French study. Clin Chem Lab Med (2014) 52:527-36. doi:10.1515/cclm-2013-0621

122. Bazarian JJ, Blyth BJ, He H, Mookerjee S, Jones C, Kiechle K, et al. Classification accuracy of serum Apo A-I and S100B for the diagnosis of mild traumatic brain injury and prediction of abnormal initial head computed tomography scan. J Neurotrauma (2013) 30:1747-54. doi:10.1089/neu.2013.2853

123. Bazarian JJ, Zhu T, Zhong J, Janigro D, Rozen E, Roberts A, et al. Persistent, long-term cerebral white matter changes after sports-related repetitive head impacts. PLoS One (2014) 9:e94734. doi:10.1371/journal.pone. 0094734

124. Metting Z, Wilczak N, Rodiger LA, Schaaf JM, van der Naalt J. GFAP and S100B in the acute phase of mild traumatic brain injury. Neurology (2012) 78:1428-33. doi:10.1212/WNL.0b013e318253d5c7

125. McMahon PJ, Panczykowski DM, Yue JK, Puccio AM, Inoue T, Sorani MD, et al. Measurement of the glial fibrillary acidic protein and its breakdown products GFAP-BDP biomarker for the detection of traumatic brain injury compared to computed tomography and magnetic resonance imaging. J Neurotrauma (2015) 32:527-33. doi:10.1089/neu.2014.3635
126. Papa L, Silvestri S, Brophy GM, Giordano P, Falk JL, Braga CF, et al. GFAP out-performs $S 100 \beta$ in detecting traumatic intracranial lesions on computed tomography in trauma patients with mild traumatic brain injury and those with extracranial lesions. J Neurotrauma (2014) 31:1815-22. doi:10.1089/ neu. 2013.3245

127. Mondello S, Linnet A, Buki A, Robicsek S, Gabrielli A, Tepas J, et al. Clinical utility of serum levels of ubiquitin C-terminal hydrolase as a biomarker for severe traumatic brain injury. Neurosurgery (2012) 70:666-75. doi:10.1227/ NEU.0b013e318236a809

128. Mondello S, Kobeissy F, Vestri A, Hayes RL, Kochanek PM, Berger RP. Serum concentrations of ubiquitin C-terminal hydrolase-L1 and glial fibrillary acidic protein after pediatric traumatic brain injury. Sci Rep (2016) 6:28203. doi:10.1038/srep28203

129. Mondello S, Palmio J, Streeter J, Hayes RL, Peltola J, Jeromin A. Ubiquitin carboxy-terminal hydrolase L1 (UCH-L1) is increased in cerebrospinal fluid and plasma of patients after epileptic seizure. BMC Neurol (2012) 12:85. doi:10.1186/1471-2377-12-85

130. McKee AC, Stein TD, Kiernan PT, Alvarez VE. The neuropathology of chronic traumatic encephalopathy. Brain Pathol (2015) 25:350-64. doi:10.1111/ bpa. 12248

131. Solomon GS, Zuckerman SL. Chronic traumatic encephalopathy in professional sports: retrospective and prospective views. Brain Inj (2015) 29:164-70. doi:10.3109/02699052.2014.965205

132. Omalu B, Hammers JL, Bailes J, Hamilton RL, Kamboh MI, Webster G, et al. Chronic traumatic encephalopathy in an Iraqi war veteran with posttraumatic stress disorder who committed suicide. Neurosurg Focus (2011) 31:E3. doi:10.3171/2011.9.FOCUS11178

133. Gandy S, Ikonomovic MD, Mitsis E, Elder G, Ahlers ST, Barth J, et al. Chronic traumatic encephalopathy: clinical-biomarker correlations and current concepts in pathogenesis. Mol Neurodegener (2014) 9:37. doi:10.1186/1750-1326-9-37

Conflict of Interest Statement: The authors declare that the research was conducted in the absence of any commercial or financial relationships that could be construed as a potential conflict of interest.

Copyright (c) 2016 Dambinova, Maroon, Sufrinko, Mullins, Alexandrova and Potapov. This is an open-access article distributed under the terms of the Creative Commons Attribution License (CC BY). The use, distribution or reproduction in other forums is permitted, provided the original author(s) or licensor are credited and that the original publication in this journal is cited, in accordance with accepted academic practice. No use, distribution or reproduction is permitted which does not comply with these terms. 